Doświadczenie mistyczne w religiach niechrześcijańskich.

Perspektywa filozoficzna „Filozofia Chrześcijańska” 17 (2020), s. 71-94

\author{
TOMASZ SIKORA
}

Uniwersytet Jagielloński

Wydział Filozoficzny

\title{
Światlo z Bezkresu - pochodzenie pleromy według dzieła Ocarot Chaim („Skarbce życia”) rabina Chaima Vitala - wstęp, thumaczenie, komentarz
}

Powszechnie znany w kręgu badaczy, wyjątkowo złożony stan źródeł do kabały luriańskiej jest wypadkową działania szeregu czynników, spośród których za najważniejsze należy uznać przede wszystkim trzy ${ }^{1}$. Po pierwsze, rabin Izaak Luria (1534-1572) prawie nie pozostawił po sobie pism autorskich (pomijając wczesny komentarz do zoharycznego tekstu Sifra de-cenijuta [Księga ukrycia] oraz nieliczne pisma homiletyczne). Po drugie, istniał szereg wzajemnie zantagonizowanych tradentów różnych wersji jego nauczania (rabini: Chaim Vital, Izrael Sarug, Józef ibn Tabul, Mojżesz Jona). Po trzecie, kabała luriańska, ta przekazywana w najbardziej rozpowszechnionej wersji rabina Chaima Vitala, stanowiła syntezę jego zapisków z nauczania Lurii z podobnymi notatkami innych uczniów, która to synteza, pod tytułem Ec chajim (Drzewo życia), w różnych wariantach przeszła przez co najmniej trzy hebrajską.

* Z wyjątkiem form rdzeni czasownikowych w tekście zastosowano uproszczoną transkrypcję

${ }^{1}$ Kwestia rozwoju piśmiennictwa luriańskiego była przedmiotem szczegółowych badań przeprowadzonych przez: R. Meroz, Geula ba torat ha-Ari (Zbawienie w pismach boskiego rabina Izaaka), Jerozolima 5748, s. 39-94 (rozprawa doktorska), J. Awiwi, Kabalat ha-Ari (Kabała boskiego rabina Izaaka), t. I-III, Jerozolima 5768 - pierwszy i drugi tom tego dzieła stanowią najbardziej analityczne omówienie wspomnianych procesów redakcyjnych. Ogólny przegląd stosownych zagadnień podają: G. Necker, Einführung in die lurianische Kabbala, Frankfurt a. M. 2008, s. 30-76; L. Fine, Physician of the Soul, Healer of the Cosmos. Isaac Luria and His Kabbalistic Fellowship, Stanford 2003, s. 16-17; K.E. Grözinger, Jüdisches Denken. Theologie - Philosophie - Mystik, FrankfurtNew York 2005, s. 619-622; Szaron Szatil, Ha-Ari. Sippura we-haguta szel mahapechat ha-kabbalah bi-Cefat, Tel Awiw 2007, s. 9-36. 
różne opracowania redakcyjne znane jako Mahdura qama (Redakcja pierwsza), Mahdura tinjana (Redakcja druga), Mahdura mecija (Redakcja środkowa). Końcowym wynikiem tego procesu była Mahdura batra (Redakcja ostatnia) uporządkowania przez rabina Jakuba Cemacha (opracowana w latach 1641-1646). Rabin Cemach zredagował materiał w postaci zbioru ośmiu pism: (1) Ocarot Chajim (Skarbce życia), (2) Kehilat Jaakow (Wspólnota Jakuba), (3) Szaar newua we-ruach ha-kodesz (Brama proroctwa i Ducha Świętego) znana również jako Szaar ha-jichudim (Brama zjednoczeń), (4) Szaar ha-gilgulim (Brama reinkarnacji), (5) Adam jaszar (Prosty człowiek), (6) Olat tamid (Wieczna ofiara), (7-8) dwa zagubione tomy egzegezy zoharycznej.

Jednak Mahdura batra była „ostatnią redakcją” tylko z nazwy, gdyż uwzględniając edycję, której podjęli się rabini Beniamin ha-Lewi i Elisza Vestali, definitywną wersję $\mathrm{w}$ ścisłym znaczeniu sporządził dopiero rabin Meir Popper (†1662), który całość spuścizny luriańskiej zredagował w postaci trzech dzieł: (1) Nof ec chajim (Wierzchotek drzewa życia), (2) Pri ec chajim (Owoc drzewa życia). (3) Derech ec chajim (Droga do drzewa życia). Ostatnie dzieło zawiera wprowadzające metafizyczne traktaty i znane jest obecnie za sprawą wydawcy, Izaaka Satanowa, jako pars pro toto Ec chajim (Drzewo $\dot{z} y(i a)^{2}$. Jak wspomniano powyżej, w redakcji rabina Jakuba Cemacha tekstem stojącym na początku luriańskiego korpusu rabina Chaima Vitala jest księga Ocarot chajim (Skarbce życia), która niewątpliwie stanowi najbardziej systematyczny i ujednolicony wykład struktury i dynamiki procesu emanacji w kabale luriańskiej, pochodzący od bezpośredniego, wybranego ucznia Lurii. W świetle skrupulatnych badań izraelskiego badacza, Józefa Awiwiego, najstarsza kopia tekstu znajduje się w zbiorze manuskryptów Biblioteki Uniwersytetu Hebrajskiego w Jerozolimie jako manuskrypt $724^{3}$. Na jego stronie tytułowej znajduje się informacja pochodząca od redaktora:

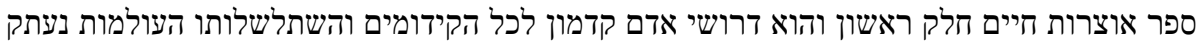

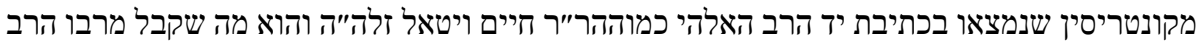

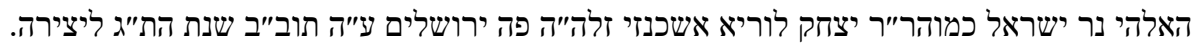

Księga Ocarot chajim, część pierwsza, komentarze dotyczące Adama Kadmona, odnośnie do wszelkich praczasów [kidummim] i łańcucha [hisztalszelut] światów, skopiowana $\mathrm{z}$ traktatów, które pochodzą z manuskryptów boskiego rabina, chwała naszemu nauczycielowi, naszemu rabinowi, geniuszowi, rabiemu Chaimowi Vitalowi, jego pamięć dla życia przyszłego świata. Oto, co otrzymał od swojego rabina, boskiego rabina, świecy Izraela, chwała naszemu nauczycielowi, rabinowi geniuszowi, rabinowi Izaakowi Lurii Aszkenaziemu, jego pamięć

${ }^{2}$ G. Necker, Einführung in die lurianische Kabbala, dz. cyt., s. 50-51.

${ }^{3}$ Dane dotyczące Ocarot chajim podaję za: J. Awiwi, Kabalat ha-Ari, t. II, s. 605-609, 727-729. 
dla życia przyszłego świata. Tutaj, w Jerozolimie, mieście świętym, niech zostanie odbudowane i ustanowione za dni naszych, roku 5403/1642 od uformowania [świata $]^{4}$.

Z kolei manuskrypt 725 omawianego tekstu zawiera Przedmowę Jakuba Cemacha, w której redaktor podaje racje skłaniające go do nadania dziełu tytułu zgodnie zaakceptowanego przez późniejszą tradycję - Ocarot chajim (Skarbce życia):

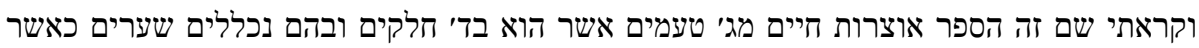

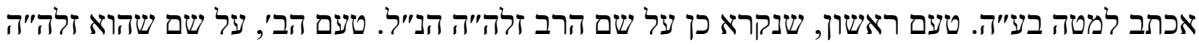

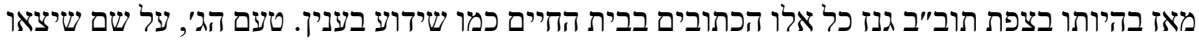

עתה לנו חיים לעבודתו ית'.

Nadałem księdze tytuł: Ocarot chajim z trzech powodów: jest ono w czterech częściach $^{5}$, w nich zaś zawierają się rozdziały [bramy], jak napiszę o tym poniżej, z pomocą ha-Szem. Powód pierwszy: zostało tak nazwane zgodnie z imieniem wspomnianego wyżej rabina [Chaim], jego pamięć dla życia przyszłego świata. Powód drugi: jako że on, jego pamięć dla życia przyszłego świata, gdy był w Cfat, niech zostanie odbudowana i ustanowiona za dni naszych, ukrył wszystkie te pisma w domu życia [bejt he-chajim - cmentarz], jak o tym wiadomo ${ }^{6}$. Powód trzeci: jako że okazały się teraz życiem [chajim] w służbie Błogosławionemu'

W świetle charakterystyki tekstu podanej w Przedmowie:

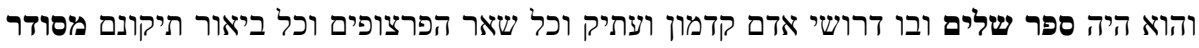

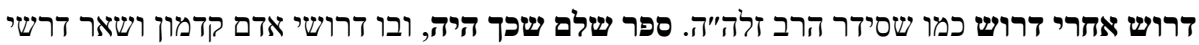

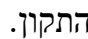

Była to księga pełna, w niej zaś wszystkie komentarze odnoszące się do Adama Kadmona, Prastarego Dni (Atik Jomin) oraz wszystkich pozostałych parcufim [konfiguracje sefirot] a także całe objaśnienie dotyczące [dzieła] ich naprawy, uporządkowane komentarz po komentarzu, tak jak uporządkował je rabin, jego pamięć dla życia przyszłego świata. Była to bowiem pełna księga, w niej zaś

${ }^{4}$ Za: J. Awiwi, Kabalat ha-Ari, t. II, s. 605.

5 Zdaniem Awiwiego, jest to błąd pisarza. Powinno być: w dwu częściach. Mowa o dziele Kehilat Jaakow, drugiej części Ocarot Chajim. Za: Awiwi, Kabalat ha-Ari, s. 606.

${ }^{6}$ Idzie o drugą redakcję - Mahdurah tinjana, którą rabin Chaim Vital ukrył w genizie na cmentarzu w Jerozolimie w czasie swojego pobytu w tym mieście w latach 1578-1585. Odkrył ją tam w 1618 r. kabalista, rabin Abraham Azulaj z Fezu, uciekający z Maroka przed prześladowaniami Żydów. Ta edycja stała się podstawą opracowania tekstu Ocarot chajim autorstwa Jakuba Cemacha. Zob.: G. Necker, Einführung in die lurianische Kabbala, s. 47.

7 Za: Awiwi, Kabalat ha-Ari, s. 606. 
wszystkie komentarze dotyczące Adama Kadmona i reszta komentarzy dotyczących [dzieła] naprawy ${ }^{8}$.

Opis rabina Cemacha wyraża wspomniany już podstawowy fakt, że pośród całej źródłowej literatury luriańskiej, pochodzącej spod pióra rabina Chaima Vitala, nie sposób znaleźć dzieła, które miałoby tak jednolity charakter i wysoce kunsztowną, spoistą konceptualną kompozycję, kontynuującą tradycję zoharycznych Idrot (Zgromadzeń). Odnosi się wrażenie, że dalej w tym kierunku posunął się tylko wielki systematyk gnozy luriańskiej, rabin Mojżesz Chajim Luzzato (1707-1746), z jego fundamentalnym opus magnum Qela"ch pitchej chochmah (138 bram mądrości) i jego skrótowym ujęciem w traktacie Kelalot ha-ilan ha-kadosz (Zasady świętego drzewa) - klasycznych przykładach uprawiania kabały w stylu analitycznym, przywołującym nie tak odległe skojarzenia z duchem Liber de causis czy wręcz Tractatus logico-philosophicus raczej, aniżeli z mistyczną egzegezą $\mathrm{w}$ duchu midraszowym.

$\mathrm{W}$ formie drukowanej dzieło wydano po raz pierwszy w 1783 roku w Korcu. Od tego czasu tekst ma wiele wydań i rozległą tradycję komentatorską sięgającą współczesności. Aktualnie na kabalistycznym rynku księgarskim w obiegu dostępnych jest około 10 jedno- lub wielotomowych edycji z osobnymi, rozbudowanymi komentarzami ${ }^{9}$.

Na koniec tej krótkiej przedmowy jedna istotna uwaga. Kluczowa dla gnostycyzmu kategoria opisująca procesy wyłaniania się rzeczywistości z różnorodnie konceptualizowanej, pierwotnej zasady wyraża się przede wszystkim $\mathrm{w}$ greckim słowie ó ó$_{\rho} \rho \mathrm{s} \alpha$, tłumaczonym na łacinę jako emanatio ${ }^{10}$. Termin á́ó $\rho \rho o 1 \alpha$ - 'wypływ', po raz pierwszy pojawia się w technicznym języku Empedoklesa z Akragas, w kontekście jego rozważań epistemologicznych. Odnosi się tam do czynnika oraz sposobu umożliwiających oddziaływania rzeczy na zmysły i odwrotnie, w myśl zasady: podobne poznaje podobne ${ }^{11}$.

${ }^{8}$ Za: tamże, s. 607.

${ }^{9}$ Za podstawę obecnego przekładu przyjęto wydanie rabina Daniela Frischa (Hajdunanas 1935 - Jerozolima 2005): Sefer Ocarot chajim im pejrusz Matok mi-dewasz (Ksiega Skarbce życia $z$ komentarzem «Stodszy od miodu»), Jeruszalajim 5768/2008, t. I, s. 1-12. Rabin Frisch uchodzi za jednego z największych izraelskich nauczycieli kabały w drugiej połowie XX wieku. Wywarł zasadniczy wpływ na sposób uprawiania kabały na jerozolimskich dworach chasydzkich Toldot Aaron oraz Toldot Abraham Izaak. Pod przydomkiem matok mi-dewasz zasłynął jako komentator całej Księgi Zohar oraz części korpusu luriańskiego. W komentarzu posługuję się materiałem egzegetycznym przytaczanym przez rabina Frischa.

${ }^{10}$ Hasło: Emanation, w: Historisches Wörterbuch der Philosopie, t. IV, red. K. Gründer, Basel 1976, s. 445-447; Reallexikon für Antikes und Christentum, red. Th. Klauser, t. IV, Stuttgart 1959, s. $1220-1227$.

${ }^{11}$ Fragment B 89 w: H. Diels, W. Kranz, Die Fragmente der Vorsokratiker, t. I, Berlin-Neuköln 1960, s. 343; fragment 390 w: G.S. Kirk, J.E. Raven, M. Schofield, Filozofia przedsokratejska, Warszawa 1999, s. 307-308. 


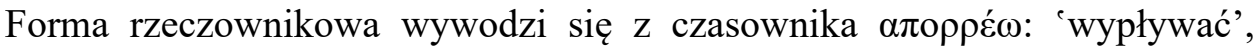
'opadać', 'rozpadać się', 'rozdzielić się', 'odpaść'12. Odmiennie rzecz się ma z hebrajskim słowem acilut, thumaczonym zazwyczaj jako 'szlachectwo', 'szlachetność', jednak w ściśle kabalistycznym znaczeniu przekładanym jako 'emanacja'. Słowo acilut derywowano jako rzeczownik abstrakcyjny od czasownikowego rdzenia ' $-c-l^{13}$. W różnych trybach koniugacyjnych ten rdzeń przejawia się w następujących znaczeniach: 'udzielić', 'natchnąć', 'odmówić', 'zabrać', 'być udzielonym', 'być natchnionym', 'natchnąc', 'nadać szlachectwo', 'nobilitować', 'być szlachetnego pochodzenia', 'połączyć', 'być złączonym'. Co najważniejsze, wspomniany hebrajski rdzeń nie wywodzi się z dyskursu filozoficznego, lecz ze starohebrajskiej tradycji profetycznej. Klasycznego przykładu takiego właśnie jego zastosowania dostarcza opis powołania 70 starszych Izraela jako elity zarządzającej plemionami wraz z Mojżeszem (Lb 11,16-17, 24-27):

Wtedy rzekł Pan do Mojżesza: „Zwołaj mi siedemdziesięciu mężów spośród starszych Izraela, o których wiesz, że są starszymi ludu i nadzorcami, i przyprowadź ich do Namiotu Spotkania; niech tam staną razem z tobą. Wtedy Ja zstąpię i będę $\mathrm{z}$ tobą mówił; wezmę [acalti] z ducha, który jest w tobie, i dam im, i będą razem $\mathrm{z}$ tobą dźwigać ciężar ludu, a ty go sam już więcej nie będziesz musiał dźwigać”. [...] I wyszedł Mojżesz, by oznajmić ludowi słowa Pana. Następnie zwołał siedemdziesięciu starszych ludu i ustawił ich wokół namiotu. A Pan zstąpił w obłoku i mówił z nim. Wziął (jaacel) z ducha, który był w nim, i przekazał go owym siedemdziesięciu starszym. A gdy spoczął na nich duch, wpadli w uniesienie prorockie. Nie powtórzyło się to jednak ${ }^{14}$.

Jak widać, z perspektywy etymologicznej pierwotną semantyczną matrycą ontologicznej koncepcji emanacji, szczególnie tej właściwej kabale luriańskiej, jest transowa propagacja kwantyfikowalnego elementu ducha (ruach), który przemieszcza się z jednostki na grupę. Warto pamiętać o tym, że pod niewątpliwie gnostycznym przykryciem kabalistycznego emanacjonizmu kryje się starsza znaczeniowa warstwa, wywodząca się z doświadczenia prorockiej ekstazy i profetycznej pneumatologii ${ }^{15}$. Wypada również zauważyć, że mocne komponenty spółgłoskowe wzmiankowanego rdzenia, głoski $c-l$ oddają ideę wizualnej lub audytywnej, cząstkowej reduplikacji elementu pierwotnego, źródłowego - przykładowo w formie cienia (cel) lub brzęku (cilcul). Kluczowy dla

12 Stownik grecko polski, red. Z. Abramowiczówna, Warszawa 1958, s. 291.

13 Pojęcie acilut jako ,emanacji” wprowadziła słynna rodzina tłumaczy, Ibn Tibbon w XII w.:

G. Necker, Einführung in die lurianische Kabbala, s. 57.

${ }^{14}$ Wszystkie cytaty biblijne za: Biblia Jerozolimska, Poznań 2006.

${ }^{15}$ Wpływy gnozy na kabałę luriańską omawia: L. Fine, Physician of the Soul, s. 144-149. 
antropologii starohebrajskiej i myśli żydowskiej termin celem należy tłumaczyć zgodnie z duchem starożytnej techniki postaciowania konturowego jako obrys cienia, kształt, zarys, co ściśle łączy się również z gnostycką ideą reduplikacji przez obrys cienia lub obraz odbicia rzucanych - projektowanych przez byt ontologicznie mocniejszy na/w byt słabszy. Klasyczne, hermetyczne ujęcie zagadnienia pojawia się w Poimandresie (14):

On, który posiadał całkowitą władzę nad światem śmiertelnych i nierozumnych zwierząt, pochylił się poprzez układ całości, rozerwał powłokę i ukazał leżącej niżej naturze piękną postać Boga. Gdy zobaczyła go jako czystą piękność i jako posiadacza wielkiej mocy zarządców i jako boską postać, uśmiechnęła się z miłością, ponieważ zobaczyła w wodzie wygląd pięknej postaci Człowieka oraz cień jego na ziemi. On zaś widząc w niej postać jemu podobną, odbijającą się w wodzie, zakochał się i postanowił tam zamieszkać. Wraz ze chceniem nadeszło i wykonanie. I zamieszkał w bezrozumnej postaci. Natura zaś wzięła ukochanego, otoczyła go całkowicie i zjednoczyli się pochłonięci miłością ${ }^{16}$.

\section{Wtóruje mu gnostyczne opracowanie tematu w Hipostazie archontów:}

Niezniszczalność spojrzała z góry na obszary wód. Jej obraz ukazał się w wodach i moce ciemności zakochały się w nim. Nie mogły jednak pochwycić tego obrazu, który objawił się im w wodach, z powodu ich słabości, psychiczni bowiem nie mogą pochwycić duchowych. [...] Archonci podjęli decyzję i rzekli: „Chodźcie, stwórzmy człowieka z prochu ziemi”. Stworzyli swoje [stworzenie] czyniąc je całkowicie człowiekiem ziemskim. Ciało, które mieli archonci, jest żeńskie, a także [męskie] o zwierzęcych twarzach. Gdy wzięli [proch] z ziemi, utworzyli [swego] człowieka według swego ciała i według obrazu Boga, jaki [im] się objawił w wodach ${ }^{17}$.

Oczywiście, emanacja przez katoptryczną reduplikację lub cień nie ogranicza się do antropogenezy, lecz ma swoje pierwotne źródło w katoptrycznej dynamice zachodzącej w obrębie samego bóstwa, co pięknie pokazuje Papyrus Berolinensis (27, 1-36):

Pojął on swe własne odbicie, gdy widział je w czystej, świetlistej wodzie, która go otaczała. Jego 'siła myślowa' (ennoia) zaczęła przejawiać swe działanie. Wystąpiła przed niego z blasku światła: jest to siła, która istniała i przejawiała się wcześniej niż wszechświat, siła będąca doskonałym „przewidywaniem” (pronoia)

${ }^{16}$ Poimandres, wstęp, przekład, komentarz W. Myszor, ,Studia Theologiae Varsoviensis” 15 (1977), $\mathrm{nr}$ 1, s. 211. Tekst omawia: H. Jonas, Religia gnozy, thum. M. Klimowicz, Kraków 1994, s. 176-180.

${ }^{17}$ Hipostaza archontów $(87,11$ i n.) w: Biblioteka z Nag Hammadi. Kodeksy I i II, tłumaczył oraz komentarzem opatrzył W. Myszor, Katowice 2008, s. 300-301. 
wszechświata, światłością, podobizną światłości, odbiciem Niewidzialnego. Jest ona doskonałą siłą, Barbēlo, doskonałym eonem chwały [...] Jest ona pierwszą „siłą myślową” (ennoia) jego (tzn. Ojca) odbiciem. Stała się ona pierwszym „człowiekiem”, jest to dziewiczy duch (pneuma $)^{18}$.

Z perspektywy semiotycznej proces emanacji w ujęciu gnostyckim ma wyraźnie charakter derywacji indeksalnej (odbicie, cień), z której w formie rudymentarnej wyłania się derywacja typu ikonicznego (obrys cienia) ${ }^{19}$. Wewnętrzna dynamika bóstwa i pierwociny kosmogenezy odwzorowują zatem proces narodzin obrazu z oznaki, który przygotowuje nadejście znaku i wkroczenie do królestwa wolności, jakim dla Charles'a Sanders Peirce’a był świat semiozy nieumotywowanej.

$\mathrm{Z}$ podobnym problemem zmaga się autor Ocarot chajim, gdy próbuje wyrazić, jak Bezkres - Ejn Sof - emanuje do wnętrza światów, które znajdują się w jego wnętrzu, lecz mimo to również i na zewnątrz niego.

Precyzja gnozy żydowskiej, której reprezentatywnym przedstawicielem jest nasz traktat, przekracza wszelkie znane mi ujęcia, obecne w gnostyckich źródłach i literaturze herezjologicznej. W części zawdzięcza to ona zapośredniczonemu przyswojeniu neoplatonizmu i arystotelizmu oraz przemawiającej $\mathrm{z}$ tła dyskursywnej pragmatyce literatury talmudycznej. Pod względem wspomnianej precyzji, a także poziomu abstrakcji i konsekwencji logicznej wywodu oraz skorelowanych $\mathrm{z}$ nim praktyk mistycznych, poniższy tekst jest w swej formie i treści bliski metafizyce izmailickiej oraz literaturze tantry buddyjskiej i hinduskiej. Jednak to zagadnienie przekracza ramy niniejszego opracowania.

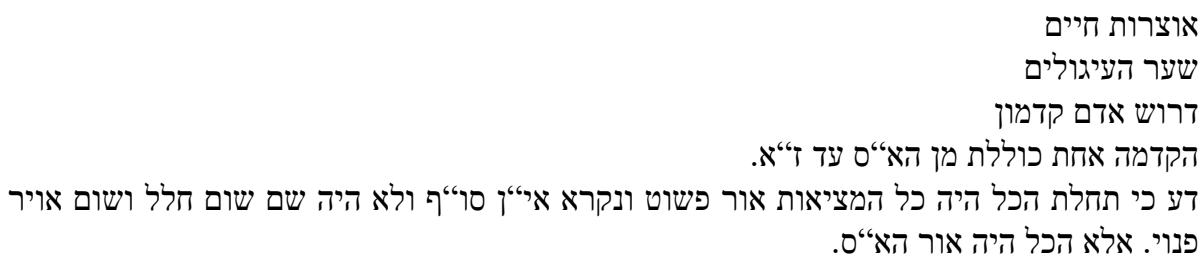

Ocarot chajim

Brama okręgów [sefirot okrężnych]

Wyjaśnienie dotyczace Adama Kadmona

Wstep obejmujący [emanacje] od Ejn Sof do Zeir Anpin

${ }^{18}$ Cyt. za: K. Rudolf, Gnoza, Kraków 2003, s. 82-83.

19 Paradoksalny charakter indeksalno-ikonicznej semiozy katoptrycznej szczegółowo analizuje: U. Eco, O zwierciadłach, w: tegoż, Czytanie świata, tłum. M. Woźniak, Kraków 1999, s. 65-102. Odnośnie do motywu cienia zob.: V.I. Stoichita, Krótka historia cienia, tłum. P. Nowakowski, Kraków 2001, s. 11-84. 
Wiedz, że na początku wszystkiego cala rzeczywistość byla prostym [rozciągniętym] światlem [or paszut], zwanym Ejn Sof. Nie bylo tam żadnej przestrzeni [chalal] ani żadnego wolnego eteru [awir panuj]. Wszystko bowiem było światłem Ejn Sof.

Zgodnie z zapowiedzią podaną na początku tekstu, obejmuje on wyłaniające się z Bezkresu (Ejn Sof) potęgi bytowe, emanacje określane nazwami poszczególnych sefirot (sefirah - 'liczenie', 'wyliczenie', 'rachuba') - w liczbie 10 - lub terminami wyrażającymi ich specyficzne konfiguracje - parcufim (1. mn. od: parcuf - 'oblicze'), występujące zasadniczo jako pentada. Sefirot to: Keter ('Korona'), Chochma ('Mądrość'), Bina ('Inteligencja'), Chesed ('Łaskawość'), Gewura ('Potęga') lub Din ('Prawo'), Tiferet ('Piękno'), Necach ('Wieczność'), Hod ('Majestat'), Jesod ('Podstawa'), Malchut ('Królestwo'). Kolejnym parcufim odpowiadają określone sefirot: parcuf Arich Anpin (,Długiego Oblicza', 'Cierpliwy') - Keter, parcuf Abba ('Ojciec') Chochma, parcuf Imma ('Matka') - Bina, parcuf Zeir Anpin ('Powściągliego Oblicza', 'Niecierpliwy') - Chesed, Gewura/Din, Tiferet, Necach, Hod, Jesod), parcuf Nukwa ('Żeńskość') - Malchut ${ }^{20}$. W porządku naprawy świata (tiqqun olam) naprawę Nukwy musi poprzedzić naprawa w obrębie Zeir Anpin. Powyższy fragment opisuje jednak stan poprzedzający wyłonienie się wszelkich emanacji. Jego podstawa bytowa charakteryzowana jest jako nieskończona i świetlista, lecz te określenia nie odnoszą się do jego istoty, lecz do jego przejawu postrzeganego z ludzkiej perspektywy. Kabała luriańska w ogóle nie wypowiada się na temat istoty (acmut) Ejn Sof, lecz poza atrybutami nieskończoności i świetlistości przypisuje mu również atrybut braku jakiejkolwiek formy celowości.

וכשעלה ברצונו (נ“א הפשוט) להאציל הנאצלים לסיבה נודעת והיא להקרא רחום וחיקים וחנון ארך אפים וכיוצא, כי אם אין בעולם מי שיקבל רחמים ממנו איך יקרא רחיל רחום, וכן עד־'ז בכל הכנויים.

Gdy zaś wzeszło w jego prostej woli, aby wyemanować emanacje, [stało się to] ze znanej przyczyny, by nazywano go milosiernym, laskawym itp. Skoro bowiem w świecie nie ma nikogo, kto by przyjąl od niego milosierdzie, jakże będzie nazywany milosiernym. Podobnie rzecz się ma z pozostałymi przydomkami

Komentatorzy podkreślają, że Ejn Sof-zawierając wszelkie cechy i pojęcia - pozostaje zasadniczo bezatrybutywny, zaś stosowane w tekstach przydomki

${ }^{20} \mathrm{~W}$ kwestii synonimicznej terminologii oraz dynamiki sefirot i parcufim $\mathrm{w}$ ich zróżnicowanych formach przejawiania zob. stosowne hasła w nieocenionych pomocach leksykalnych: E. bar Chaim Chalfon, Milon 'iwri kabbali (Hebrajski stownik kabalistyczny), Nof Ajjalon 5758/1998; R. Afilalo, Kabbalah Dictionary, [b.m.] 2005. 
takie jak rachum - 'miłosierny', czy chanun - 'łaskawy' i inne odnoszą się do sefirot. Główne biblijne źródło tych określeń stanowi enumeracja trzynastu miar miłosierdzia występująca u proroka Micheasza [Mich 7,18-20]. Rabin Frisch jest wyrazicielem długiej tradycji kabały teozoficzno-teurgicznej, gdy twierdzi, że człowiek, wypowiadając przydomki sefirot, sprowadza do nich światło Ejn Sof, co skutkuje ich oczyszczeniem i pobudzeniem. System sefirot spełnia również funkcje mediacyjne, gdyż tylko za jego pośrednictwem człowiek otrzymuje wsparcie płynące w istocie ze źródła Ejn Sof. Wypowiadając imiona sefirot z właściwą intencją (kawwana), co wynikać ma z należytego połączenia stosownych stanów skupienia $\mathrm{z}$ aktami intensywnej wizualizacji, człowiek naprawia siebie oraz świat i równoprawnie współuczestniczy w cyrkulacji elementu szefa, rozpoznając siebie jako zanurzonego w permanentnym akcie stworzenia - creatio perpetua ${ }^{21}$. Według rabina Salmana Eliasza ben Józefa, autora znanego dzieła Kerem Szlomo (Winnica Salomona) - komentarza do Ec chajim rabina Vitala: „Gdyby bowiem nie było pracy związanej z zapanowaniem nad złym popędem, wówczas wszystkie dobrodziejstwa przyszłego świata byłyby niejako za darmo, co wszak nazywa się jałmużną [nechama de-kasufa]"22.

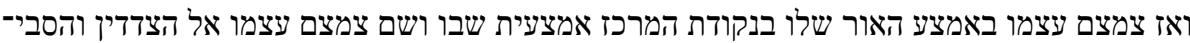
בות ונשאר חלל בנתיים, וזה היה צמצום הראשון של המאציל העליון.

Wówczas ograniczył siebie w środku swojego światła, w centralnym punkcie środkowym, który był w nim. Tam ograniczył siebie ku wszystkim stronom oraz wszystkim okolicom [kierunkom] i pozostała między nimi przestrzeń. To było pierwsze ograniczenie wyższego emanatora.

Cimcum jako samoograniczenie Bezkresu ma umożliwić zaistnienie sfery skończonej wraz z jej światami i mieszkającymi w nich istotami. W ten sposób wyłoniła się sfera, w której pierwotne światło po swoim wycofaniu występuje wyłącznie w postaci śladowej (reszimu - 'ślad'). Ono posłuży do budowy naczyń (kelim), do których spłynie w procesie emanacji światło Ejn Sof. Emanacja to $\mathrm{w}$ istocie proces wlewania się światła Bezkresu w reliktowe światło śladowe, które w ten sposób stanowi wyjściowy materiał budulcowy świata/ /światów. W istocie rzeczy jest to pierwsze, wzorcowe cimcum, po którym przyjdą jeszcze szeregi następnych ograniczeń (cimcumim), które zachodzą

${ }^{21}$ Nieoceniony materiał ilustracyjny pokazujący złożone techniki medytowania na sefirot w pismach rabina Izaaka ben Samuela z Akko (XIII/XIV) przynosi: E.P. Fishbane, As Light Before Dawn. The Inner World of a Medieval Kabbalist, Stanford 2009, s. 178-247.

22 Za: Sefer Ocarot chajim im pejrusz Matok mi-dewasz, s. 2: 
zawsze, gdy wyłania się kolejny byt skończony. Samoograniczenie Bezkresu rozumiane jest jako przejście od potencji do aktu. W tym procesie to, co bezgraniczne i bezcelowe, przyjmuje postać skończoną, ukierunkowaną teleologicznie, co w sposób oczywisty domagało się i każdorazowo domaga umniejszenia pierwotnego fotycznego potencjału, jego bowiem nadmiar zagraża zniszczeniem naczyń. Tak jak w pierwotnym cimcum, zawsze ograniczone otoczone jest przez nieskończone, a tę relację konceptualnie wyraża się przez geometryczną metaforę wnętrza i zewnętrza okręgu. W związku z tym mowa jest o świetle obejmującym i obejmowanym. W kategoriach panenteistycznych obowiązuje formuła, w myśl której Ejn Sof jest miejscem świata, lecz świat nie jest jego miejscem.

וזה מקום החלל הוא עגול בהשואה אחת מכל צדדיו, עד שנמצא עולם החיפ האצילות וכל העולמות נתונים

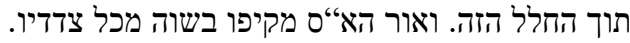

To jest miejsce tej przestrzeni okrągłej $w$ doskonałej proporcji $z$ każdej strony. Aż do wystąpienia świata emanacji i wszystkich światów, które dane są wewnątrz tej przestrzeni. Światło Ejn Sof obejmuje ją równo z każdej strony.

Wyrażenie „miejsce tej przestrzeni” (makom he-challal) odnosi się do potencjalnej przestrzeni wyłaniających się światów, zaistniałej właśnie dzięki cimcum. W literaturze rabinicznej słowo makom ('miejsce') było jednym z przydomków bóstwa, co wynikało z egzegezy tego słowa jako występującego w epizodzie ofiarowania Izaaka ( $\mathrm{Rdz} 22)$, oraz tym dotyczącym tzw. „drabiny" Jakubowej i przemianowania nazwy Luz na Betel (Rdz 28,10-32). Stosowna egzegeza midraszowa kulminowała semantycznie w znanej wypowiedzi z midraszu Jalkut Szimoni: „On jest miejscem świata, lecz świat nie jest jego miejscem" "23. W kabale preluriańskiej słowo makom łączy się zasadniczo z sefira Tiferet, ściśle powiązaną z Tetragramem. Zwraca się przy tym uwagę na fakt, że wartość gematryczna słowa, 186, odpowiada wartości łącznej drugich potęg literoliczb Tetragramu. Inspirując się Sefer Jecira (I, 15), na zasadzie pars pro toto sefirę Tiferet określano jako sześć kierunków kardynalnych (szesz kicwot) wraz z odpowiadającymi im sefirot: południe - Chesed, pó1noc - Gewura, zachód - Tiferet, wschód - Jesod, góra - Necach, dół - Hod. $\mathrm{Z}$ kolei rabin Mojżesz z Leonu kojarzył kategorię makom z sefirą Keter ${ }^{24}$.

23 Jalkut Szimoni, Wilno 1909 [reprint b.d. i m.], t. I, s. 72, remez. 117:

קוראין אותו מקום מפני שהוא מקומו של עולם ואין העולם מקומו.

${ }^{24}$ Za: hasło: Makom, w: M. Kordowero, Pardes rimmonim [Ogród granatów], Jeruszalajim 5760/2000, s. 354 . 
והנה כאשר צמצם עצמו אז דרך צד אחד מן החלל העגול הזה המשיך אור דרך קו אחד ישר דק כעין

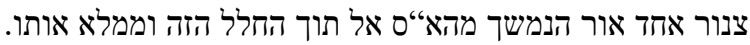

Oto zaś, gdy [Ejn $S o f]$ ograniczył siebie, wówczas przez jedną ze stron $\mathbf{z}$ tej okrąglej przestrzeni rozciągnęlo się światło przez jedną cienką, prostą linię, jakby przez jedną rurkę, światło rozciągające się od Ejn Sof do wnętrza tej przestrzeni i wypełniające ją.

W tekście pojawiają się synonimiczne określenia: prosta linia (kaw jaszar) i delikatny kanalik (cinnor dak). Służą one opisowi interakcji pomiędzy wkraczającym z zewnątrz okręgu światłem Ejn Sof i obecnym wewnątrz niego reliktowym, umniejszonym światłem śladu (reszimu), określanym również jako „korzeń wszystkich stworzeń” (szoresz kol ha-niwraim) ${ }^{25}$. Z niego właśnie powstała wspomniana linia/kanalik, której przebieg ustanawia kierunki góra - dół, a w konsekwencji przestrzeń heksagonalną Zeir Anpin. Według rabina Frischa tak jak ciało pozbawione jest bytu bez mocy tchnienia, które się weń ubiera, tak też ta przestrzeń, to znaczy ślad (reszimu) nie ma żadnego innego bytu, jak tylko dzięki światłu Ejn Sof, który rozciąga się poprzez linię, rozprzestrzenia się w niej i utrzymuje jej istnienie.

אבל נשאר מקום פנוי בין האור שבתוך חלל זה ובין אור הא"ם המקיף המיף את זה החלל כנז' שנתצמצם אל צדדיו וסיום הקו הזה למטה אינו נוגע ג׳"כ באור הא"ם עצמו.

Jednak pomiędzy światlem wewnątrz tej przestrzeni i obejmującym ją światłem Ejn Sof, który dokonal ograniczenia ku stronom, pozostało wolne miejsce. Koniec tej linii na dole nie dotyka bowiem samego światła Ejn Sof.

Zazwyczaj diagramy kabalistyczne ukazują linię prostą lub delikatny kanalik jako dochodzące do długości około trzech czwartych średnicy okręgu reprezentującego sferę cimcum $^{26}$. Oznacza to, że między końcem linii/kanaliku pozostaje wolna przestrzeń. W przeciwnym razie doszłoby do przecięcia okręgu/sfery i całkowitego zlania się dwu wspomnianych rodzajów świateł pełnego i umniejszonego, o czym mówi następny wers.

שאם לא כן יחזור הדבר לכמות שהיה ויחזור ויתחבר האור הזה שבתוך החלל עם אור הא“ם יחד

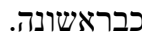

Gdyby tak się nie stało, rzecz wrócilaby do stanu poprzedniego. To światlo, które jest $\mathrm{w}$ tej przestrzeni, powróciłoby i połączyło się razem ze światlem Ejn Sof tak jak na początku.

${ }^{25}$ Sefer Ocarot chajim im pejrusz Matok mi-dewasz, s. 5.

${ }^{26}$ Zob. anonimowe dzieło prezentujące doktrynę luriańską w formie diagramatycznej: Derech le-Ec chajim Tarszimej hesber le-hawanat sefer Ec Chajim, Szaar ha-kawwanot u-moadim, Tiferet Szlomoh, 5767/2007, s. 1; D. Kafasjan, Sefer Ec chajim sze be-gan, [b.m.] 5769/2009, s. 41. 
Gdyby nie wspomniana wolna, dolna przestrzeń występująca między końcem linii/kanaliku a obwodem okręgu, sfera cimcum uległaby rozpuszczeniu w Ejn Sof, co skutkowałoby powrotem do pierwotnego stanu Bezkresu.

ועל כן לא נתפשט ונמשך האור הזה ברוחב אל תוך החלל רק דרך קו אחד דק לבד כנז'

Dlatego też to światło nie rozprzestrzeniło się i nie rozciągnęlo na szerokość, do wnętrza tej przestrzeni, lecz tylko poprzez jedną cienką, delikatną linię, jak wspomniano.

Celem ograniczonej ekspansji światła przez linię jest takie jego umniejszenie, aby każdy byt jako naczynie otrzymał je wedle stosownej dla siebie miary. O linii tej mówi się jako o odzieniu (lewusz, malbusz), w które ubiera się pierwotne światło, aby dostosować się do możliwości stworzeńn ${ }^{27}$. Nadmiar lub niedomiar światła prowadzi bowiem do ich unicestwienia (hitbatlut).

ודרך הקו הזה נמשך ויורד אור הא“"ם המאציל אל תוך החלל העגול הזה שהוא הנאצל ועם“י כן מתדבקים המאציל בנאצל יחד ולר ולא עוד.

Przez tę linię zaś wyemanowane światło emanującego Ejn Sof rozciąga się i zstępuje do wnętrza tej okrąglej przestrzeni. Dzięki temu lączą się [hitda$w e q$ - dosłownie: 'sklejają się'] razem emanator $\mathbf{z}$ tym, co emanowane. I tyle.

Rabin Frisch komentuje ten wers następująco:

Przez tę linię zaś, która jest niczym rurka i szata, rozciąga się i zstępuje do jego wnętrza światlo wyższego, emanującego Ejn Sof do wnętrza tej okrągłej przestrzeni, aby jego światłem ożywić wszystkie stworzenia, gdyż ona, to znaczy, ta przestrzeń została wyemanowana jako pierwsza. Wszystkie bowiem światy zostały wyemanowane i stworzone w jej wnętrzu. Dzięki temu, dzięki tej linii, która rozprzestrzeniła się do wnętrza przestrzeni, sklejają się razem emanator, który jest otaczającym światłem Ejn Sof, i to, co emanowane, to znaczy, miejsce tej przestrzeni i wszystkie światy w jej wnętrzu, występujące jako ograniczone. Za sprawą tej linii razem łączą się i sklejają światło emanatora z tym, co wyemanowane. Wszelka więź stworzeń ze światłem Ejn Sof zachodzi przez tę linię, która przyodziewa światło i ogranicza je. I tyle, i nie ma innego światła, dzięki któremu stworzenia łączą się i sklejają ze światłem Ejn Sof, niech będzie błogosławiony, gdyż zaistniała tylko jedna linia, z jednej strony ${ }^{28}$.

${ }^{27}$ Zoharyczne ujęcie ontologii „odzienia” szczegółowo omawia: D. Kohen-Alloro, Sod ha-malbusz u-mareh ha-malaach be-sefer ha-Zohar, Jeruszalajim 1987, s. 12-16.

${ }_{28}^{28} \mathrm{Za}$ : Sefer Ocarot chajim im pejrusz Matok mi-dewasz, s. 6-7:

"ודרך הקו הזה שהוא כעין צנור ולבוש נמשך ויורד בתוכו אור האין סוף המאציל העליון, אל תוך החלל העגול הזה להחיות 


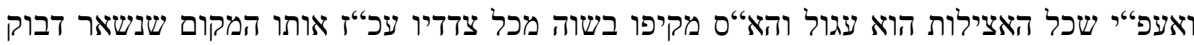

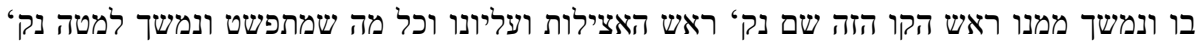

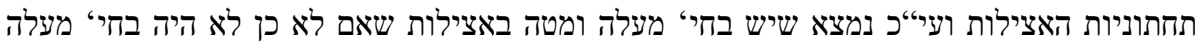
ומטה וראש ורגלים באצילות.

Za sprawą tego, że cala emanacja zachodzi w formie okręgu, Ejn Sof obejmuje ją równomiernie $z$ każdej $\mathrm{z}$ jej stron, a wraz $\mathrm{z}$ nią to właśnie miejsce, które pozostało $\mathrm{z}$ nim sklejone. $\mathrm{Z}$ niego rozciąga się ta linia i nazywa się je początkiem emanacji i jego górą [rosz ha-acilut we-eljono]. Wszystko zaś, co rozprzestrzenia się i rozciąga w dól, nazywa się dolnymi elementami [tachtonijot] emanacji. W ten sposób odkrywamy, że w emanacji występują aspekty góry i dołu [mala u-mata]. Gdyby tak nie było, w emanacji nie występowałyby aspekty góry i dołu, glowy i nóg.

Górna część linii emanacji, połączona ('sklejona') z równomiernie wszechobejmującym Bezkresem, odpowiada sefirze Keter (określanej również jako „Głowa”), poniżej której rozpościera się sfera określana jako łańcuch stopni (dosłownie: łańcuchowienie się stopni - hisztalszelut ha-madregot), niższych sefirot aż do Malchut (określanej również jako „Nogi”), zawierającej czasowo-przestrzenne, materialne uniwersum. Światło ekspandujące w przestrzeni sferycznej jako linia ulega stopniowemu zagęszczeniu i umniejszeniu. Dynamicznie zmienny rozkład kondensacji światła wyznacza kierunki góry i dołu, w obrębie których przejawiają się światy w różnych formach.

והנה האור הזה המתפשט בתוך החלל הזה נחלק לב' בחי': האחת היא כי הנה כל האורות שלות שבתוך זה

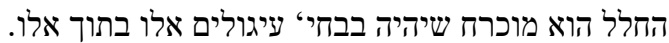

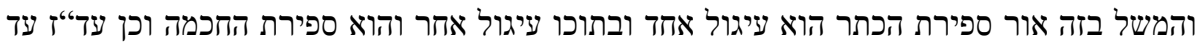

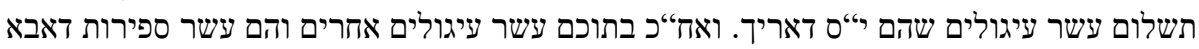

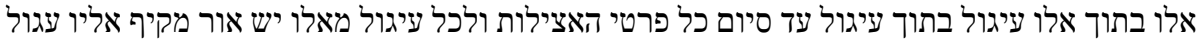

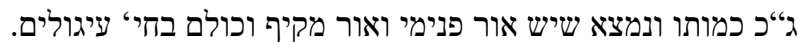

To światlo, rozprzestrzeniające się wewnątrz tej przestrzeni, rozdzieliło się na dwa aspekty. Jeden $z$ nich polega na tym, że wszystkie światła, znajdujące się wewnątrz tej przestrzeni, w sposób konieczny występują w formie okręgów - jedne w drugich.

Przykładowo, światło sefiry Keter stanowi jeden okrąg. W jego wnętrzu znajduje się inny okrąg, który odpowiada sefirze Chochma. W ten sposób aż 
do dopelnienia się dziesięciu sefirot, które są sefirami Arich Anpin [„Długie Oblicze", parcuf Keter Adama Kadmona]. Po tym zaś, w ich wnętrzu, znajduje się dziesięć innych okręgów, dziesięć sefirot okręgów [parcuf] Abba, jedne w drugich, okręg wewnątrz okręgu, aż do zakończenia wszystkich elementów emanacji.

Dla każdego okręgu spośród nich istnieje światlo obejmujące, tak jak on okrągle. Zatem jest światło wewnętrzne i światło obejmujące, wszystkie one zaś stanowią aspekt okręgów.

Światło emanujące w formie okręgów odpowiada ontologicznie działaniu deterministycznego porządku natury - tewa. W literaturze midraszowej znaczy ono 'podstawa', 'żywioł'. Tworzący je rdzeń w podstawowej formie czasownikowej przynosi m. in. znaczenia: 'tonąć', 'zapadać się', 'grzęznąć', 'pogrążać się'. Podleganie wyłącznie prawom tewa oznacza utratę wolności. W budowie niesubtelnych i subtelnych warstw ludzkiego ciała odpowiada mu element duszy wegetatywnej nefesz korespondujący z elan vital światów określaną terminem chijjunijut (,żywotność"). Wszystkie światła obecne w elemencie nefesz pochodzą wyłącznie z reliktowego światła śladu (reszimu). Idea koncentrycznej i ciągłej emanacji oznacza, że emanacje bytowo pierwotne stanowią wnętrze zewnętrza, którym są emanacje ontologicznie w różnym stopniu wtórne.

והבחינה הב' היא כי הנה באמצע כל האצילות הזה העגול מתפשט דרך קו הישר בחי' אור דוגמת

העיגול ממש רק שהוא ביושר היא כינה

Drugi aspekt polega na tym, że oto w środku całej tej okrężnej emanacji rozprzestrzenia się poprzez prostą linię światło, w formie rzeczywistego okręgu, tyle że występującego jako prosta linia.

Światłu emanującemu w formie prostej linii - kanaliku - odpowiada działanie elementu pozwalającego na wykroczenie poza porządek deterministyczny właściwy efektom działania sefirot okrężnych. Na planie antropologicznym odpowiada mu element ruach, wytwarzający przestrzeń wolności, odstęp (rewach) pomiędzy elementami ciągu przyczynowo-skutkowego. Prosta linia przyjmuje postać człowieka (Adam Kadmon) o 248 członkach i 365 ścięgnach korelujących z 248 nakazami ('czyń') i 365 zakazami ('nie czyń'), które składają się na budowę rytualnego szkieletu judaizmu w postaci 613 przykazań (micwot), ich znaczeń (teamim) i odnoszących się do nich intencji (kawwanot). To właśnie posłuszeństwo względem micwot sprawia, że ich wykonawcy nie pogrążają się ostatecznie w deterministycznym porządku natury, lecz kierując się właściwym poznaniem, przechodzą dzieło naprawy. Według litewskiego kabalisty ze szkoły Gaona z Wilna, rabina Izaaka Ajzyka 
Chawera (1789-1853), autora kluczowego komentarza do Ec chajim - Pitchej szearim (Warszawa 5648/1888):

W prowadzeniu [hanhaga] linii prostej kryje się tajemnica [wolnego] wyboru i wypełniania micwot. Dzięki temu aspektowi synowie Izraela działają na rzecz napraw wszystkich światów wyższych i wszystko w górze podlega działaniu wedle czynu synów Izraela. Gdy wzmagają pracę i wypełniają micwot, wzmaga się w nich wpływ [szefa]. Gdyby jednak, oby tak nie było, nie wypełniali micwot i umniejszyli pracę, zmniejszy się w nich [obecność] wpływu. Wszelkie stworzenia są zależne od tej sprawy. Taki był bowiem cel stworzenia, to znaczy [wolny] wybór. Dzięki temu zachodzi prowadzenie synów Izraela z wielką skrupulatnością, $\mathrm{z}$ indywidualną opatrznością $\mathrm{w}$ stosunku do każdej jednostki, wedle tego co należy się każdemu wedle jego czynów. Ten stopień linii prostej odpowiada aspektowi wewnętrznemu [pnimijut] świata okręgów. Jednak w odniesieniu do narodów świata ich prowadzenie zachodzi w aspekcie okręgów w zewnętrznym wymiarze [chiconijut] światów, to znaczy wedle natury [tewa], która zatonęła $[$ nitba] na początku stworzenia w łasce [chesed] Jego, niech będzie błogosławiony. Natomiast Izrael, któremu dano Torę i micwot, istnieje w obrębie wewnętrzności światów i opatrzności linii prostej, czemu odpowiada doskonała pozycja [qoma szlima] linii i członków zgodnie z drogami Tory i jej bohaterów. Również prowadzenie narodów świata zmienia się zgodnie $\mathrm{z}$ wewnętrznością światów, gdyż pośród nich zatrzymani przebywają synowie Izraela, a wedle ich pracy zmienia się prowadzenie całej natury ${ }^{29}$.

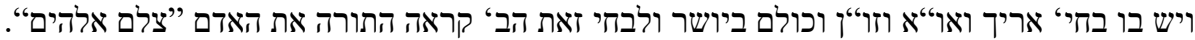

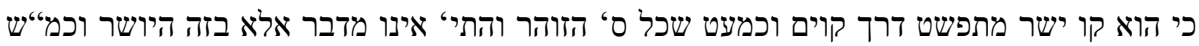

${ }^{29}$ Za rabinem Frischem: Ocarot chajim..., s. 10:

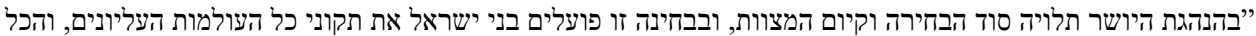

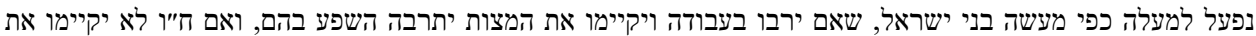

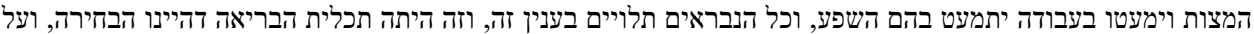

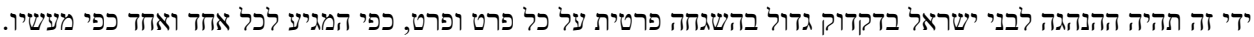

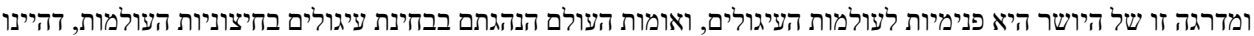

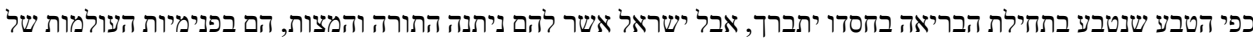

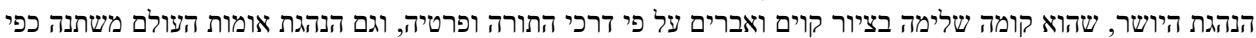

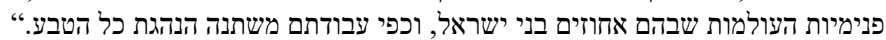

Zagadnienie dialektyki występowania sefirot w formie okręgów oraz linii prostej w kabale luriańskiej w ujęciu rabina Vitala oraz w dziełach jej twórczych kontynuatorów (rabini: Emanuel Chaj Ricci, Szlomo Eljasziw, Josef Ergas, Mosze Chaim Luzzatto, Abraham Izaak Kuk i in.) w sposób systematyczny prezentują: M. Pachter, Circles and Straightness, w: tegoż, Roots of Faith and Devequt. Studies in the History of Kabbalistic Ideas, Los Angeles 2004, s. 131-184; R. Shuchat, Hagigim al qabbalat Lita. Ijun be-sugijat igulim we-joszer, w: Mincha le-Sara. Mechkarim bafilosofija jehudit u-wa-qabbala mugaszim la-profesor Sara Heller Wilenski, red. M. Idel, D. Dimant, S. Rozenberg, Jeruszalajim 1994, s. 11-32. 
Istnieje w niej aspekt: Arich, Abba i Ima, Zeir oraz Nuqwa. Wszystkie one występują $w$ linii prostej. $Z$ powodu tego drugiego aspektu Tora nazwala czlowieka (Wj 1, 27) celem elohim. Jest to prosta linia ekspandująca poprzez linie. Prawie cała księga Zohar oraz Tikkunim mówią wyłącznie o tej prostej linii, co objaśnimy poniżej.

Ponownie oddajmy głos rabinowi Frischowi:

Istnieje w niej, w tej prostej linii, aspekt oblicz [parcufim] Arich, Abba i Ima, Zeir i Nukwa. Jest to pięć oblicz występujących w Praczłowieku i we wszystkich światach spośród światów emanacji stwarzania, formowania i czynienia. Wszystkie one występują w linii prostej - niczym wyprostowana postać człowieka, który ma głowę, tułów, ręce i nogi. $\mathbf{Z}$ powodu tego drugiego aspektu Tora nazwala czlowieka (Wj 1,27) celem elohim. Jak napisano: „I stworzył elohim człowieka wedle jego celem, wedle celem elohim stworzył go". To znaczy, na obraz i podobieństwo tej prostej linii, w której jest 248 członków i 365 ścięgien wobec występujących w Torze 248 micwot pozytywnych i 365 micwot negatywnych. [...] Dlatego nazwano człowieka celem elohim. Powiedziano też, że światy prostej linii występują $\mathrm{w}$ aspekcie prostej linii ekspandującej poprzez linie. Znaczy to, że ta linia w szczegółach rozdziela się na trzy linie: prawą, lewą i środkową - na podobieństwo oblicza człowieka, który stoi liniowo wyprostowany. Znaczy to, że ten człowiek zawiera trzy mózgi (mochin) w następujący sposób: Chochma po prawej, Bina po lewej i Daat w środku. Również tułów i dwa ramiona, którym odpowiada tajemnica Chesed - prawe ramię, Gewura - lewe ramię, Tiferet - tułów w środku. Tak jest również z dwoma nogami i świętym przymierzem, które w tajemnicy odpowiadają: Necach - prawa noga, Hod - lewa noga, Jesod - święte przymierze, w środku ${ }^{30}$. W porządku liniowym występują: Chochma, Chesed, Necach - linia prawa, Bina, Gewura, Hod - linia lewa, Daat, Tiferet, Jesod - linia środkowa. Prawie cala księga Zohar oraz Tikkunim, gdy wypowiadają się w kwestii światów i sefirot, mówią wyłącznie o tej prostej linii, która zawiera wszystkie szczegóły światów Praczłowieka: emanacji, stwarzania, formowania i czynienia. Od niej zależy praca synów Izraela, jak wspomniano wyżej. Co objaśnimy poniżej (w Ec Chajim, Brama okręgów i linii prostej)"31.

ודע כי בזה האצילות יש מיני עולמות לאין קץ ואין אנו עתה בביאורם

Wiedz, że w tej emanacji istnieje nieskończenie wiele światów różnych rodzajów, lecz nie zajmujemy się teraz ich objaśnieniem.

${ }^{30}$ Pojęcie „świętego przymierza” odnoszące się do sefiry Jesod („Podstawa”) odsyła do przymierza bóstwa z Abrahamem, szczególnie zaś nakazu dokonywania obrzezania w dniu ósmym od urodzenia. Przez rozszerzenie metonimiczne to wyrażenie stanowi również określenie membrum virile. Jesod kojarzona jest z płodnościowym aspektem formy El Szaddaj.

${ }^{31}$ Ocarot Chajim..., s. 10. Klasyczne omówienie znaczenia idei celem w kabale podaje: G. Scholem, Celem - wyobrażenie ciała astralnego, w: tegoż, O mistycznej postaci bóstwa, thum. A.K. Haas, Warszawa 2010, s. 297-329. 
Hebrajskie słowo olam, tłumaczone zazwyczaj jako świat lub wiek/eon, wyraża semantyczną fuzję czasowo przestrzenną i odnosi się do jakościowo odrębnych długich okresów przynoszących serię specyficznych wydarzeń. Olam to pewien świat powstający, trwający i zanikający jako odrębny tunel zdarzeń - trwanie periodyczne w zamkniętym kontinuum. To zarazem pojęcie oddające ideę wieczności w odróżnieniu od przemijającej doczesności. Formie rzeczownikowej tego pojęcia odpowiada rdzeń ' $-l-m$, który w różnych trybach koniugacyjnych owocuje znaczeniami: 'być ukrytym, tajemnym', 'coś ukrywać', 'ukrywać się', 'znikać', 'stawać się nieuświadamianym', 'pomijać', 'lekceważyć', 'nie zważać na coś'. Z perspektywy semantyki kognitywnej $\mathrm{w}$ hebrajskim pojęciu świata jako procesualnego interwału zdarzeń zagnieżdża się poznawczy schemat stanu ukrywania się i ukrywającego się elementu z jego ulotną i złudną dostępnością poznawczą. Zachodzi również odwrotny proces rzutowania pól semantycznych przebiegu zdarzeń i ich zagadkowego charakteru. Z perspektywy rekonstrukcji starohebrajskiej metafizyki w ujęciu Oskara Goldberga: „Olam jest czasem, który postrzega się i osądza z perspektywy jego «jeszcze nieobecnej części», nieskończoności"32. Mowa jest również o świecie obecnym (olam ha-ze) oraz o nacechowanym mesjanicznie świecie, który ma nadejść (olam ha-ba). W kontekście procesu emanacyjnego mówi się w kabale luriańskiej o czterech światach, są: (1) świat emanacji (olam ha-acilut), (2) świat stwarzania (olam ha-brija), (3) świat formowania (olam ha-jecira), (4) świat czynienia (olam ha-asja). Tylko jeden spośród nich świat emanacji - należy do sfery boskiej. Jako taki określany jest wyrażeniem „świat zrównoważony” (olam ha-matqela) i składa się z pięciu parcufim ${ }^{33}$. Ostatecznie jednak liczba światów jest nieskończona, co odpowiada fraktalnej ontologii sefirot oraz naturze samego Ejn Sof. Termin olam może odnosić się również do poszczególnych sefirot. Przykładowo, wspomniana sefira Jesod określana jest w kabale zoharycznej mianem ,świata dusz" (olam ha-neszamot), gdyż w niej dusze rozkwitają i spływają ku Szechinie, czyli Malchut ${ }^{34}$.

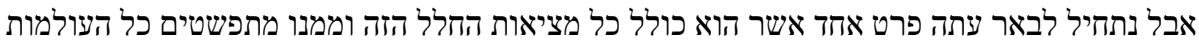

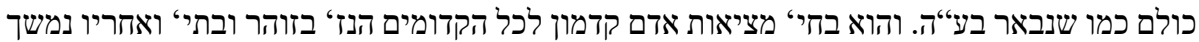

סדר כל המדרגות כולם.

32 O. Goldberg, Rzeczywistość Hebrajczyków, tłum. T. Sikora, Kraków 2012, s. 14.

${ }_{33}$ G. Necker, Einführung in die lurianische Kabbala..., s. 57.

${ }^{34}$ M. Kordowero, Pardes rimmonim, Jeruszalajim 5760/2000, s. 364. Pojęcie Szechiny jako żeńskiej formy obecności bóstwa we wczesnej literaturze rabinicznej analizuje m.in.: A.M. Goldberg, Untersuchungen über die Vorstellung von der Schekhinah in der frühen rabbinischen Literatur, Berlin 1969, s. 439-538. Wstępnego przeglądu materiału kabalistycznego dokonał: G. Scholem, Szechina - bierno-żeński moment w bóstwie, w: tegoż, O mistycznej postaci bóstwa, Warszawa 2010, s. 157-226. Najnowsze, obszerne studium postaci Szechiny w późnej literaturze zoharycznej przynosi rozprawa: B. Roi, Ahawat ha-Szechina. Mistika u-poetika ba Tikkunej Zohar, Ramat Gan 5767/2007. 
Jednak obecnie zaczniemy objaśniać pewien element [prat], który zawiera całą rzeczywistość tej przestrzeni. $Z$ niego ekspandują wszystkie światy, jak objaśnimy to z pomocą ha-Szem. Mowa o aspekcie rzeczywistości Praczlowieka, który poprzedza wszystko. Wspomina się o nim w księdze Zohar i w Tikkunim. Po nim rozciąga się porządek wszystkich stopni.

Tekst wprowadza temat człowieka kosmicznego, megantroposa, jako elementu, z którego wszystkie emanacje wyłaniają się w formie ,wielkiego łańcucha bytu". To kabalistyczna wersja zasady antropicznej w jej najsilniejszym sformułowaniu, o której literatura zoharyczna wypowiada się w nielicznych miejscach, zawsze wyłącznie przez ewokatywne aluzje ${ }^{35}$. W istocie, całość emanowanej rzeczywistości postrzegana jest jako ontologicznie zależna od wydarzeń zachodzących w pleromatycznym ciele Praczłowieka ${ }^{36}$.

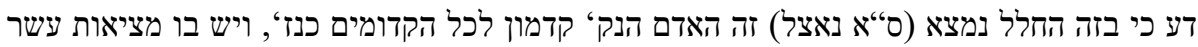

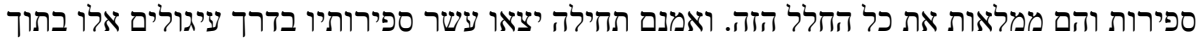

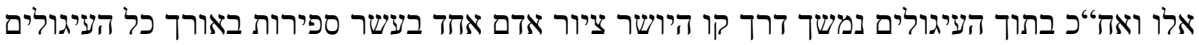

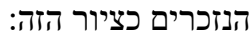

Wiedz, że w tej przestrzeni znajduje się [wyemanowany] ten właśnie człowiek, zwany Praczlowiekiem, jak wspomniano - uprzedni względem wszystkiego. W nim występuje rzeczywistość dziesięciu sefirot, które wypełniają całą tę przestrzeń. Początkowo dziesięć sefirot zstąpilo w formie okręgów jedne w drugich. Następnie zaś we wnętrzu okręgów, w dziesięciu sefirot, rozciągnąl się poprzez prostą linię wizerunek człowieka - na długość wszystkich wspomnianych okręgów, tak jak na tym rysunku. [RYSUNEK 1]

Rabin Vital dookreśla funkcję Praczłowieka jako zasady wolnego wyboru wyrażającej się przez dynamikę sefirot linii prostej, odmienną od ściśle deterministycznych procesów natury, podtrzymywanej w istnieniu przez okrężne sefirot. Według rabina Frischa okręgi poprzedzają wystąpienie linii prostej, tak jak pojawienie się duszy (nefesz) człowieka poprzedza nadejście ducha (ruach). Jego zdaniem, pełny schemat przedstawiający interakcję sefirot $\mathrm{w}$ formie okręgów i linii prostej powinien wyglądać następująco: [RYSUNEK 2]

ואין אנו עוסקים כלל בעיגולים רק בבחי' היושר בלבד. ולהלן נבאר מציאות העיגולים והיושר מה עניינם.

W ogóle nie zajmujemy się okręgami, lecz wyłącznie aspektem linii prostej. Poniżej objaśnimy, jak się mają sprawy z rzeczywistością okręgów i [linii] prostej.

35 Ocarot Chajim..., s. 11.

${ }^{36}$ Zarys genezy idei człowieka kosmicznego na gruncie mistyki żydowskiej podaje: M. Idel, Kabała. Nowe perspektywy, tłum. M. Krawczyk, Kraków 2006, s. 211-230. 


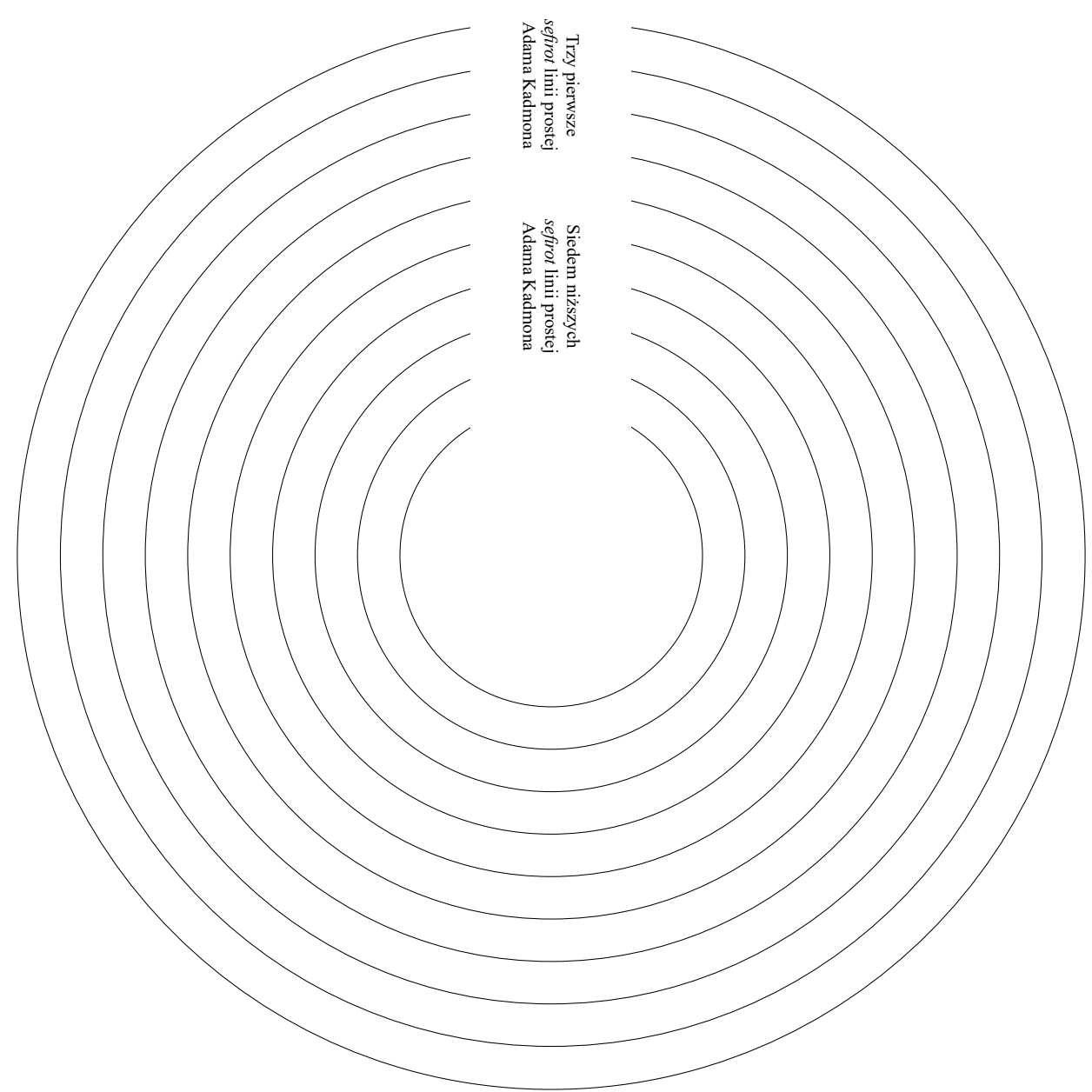

Sefirot linii prostej 


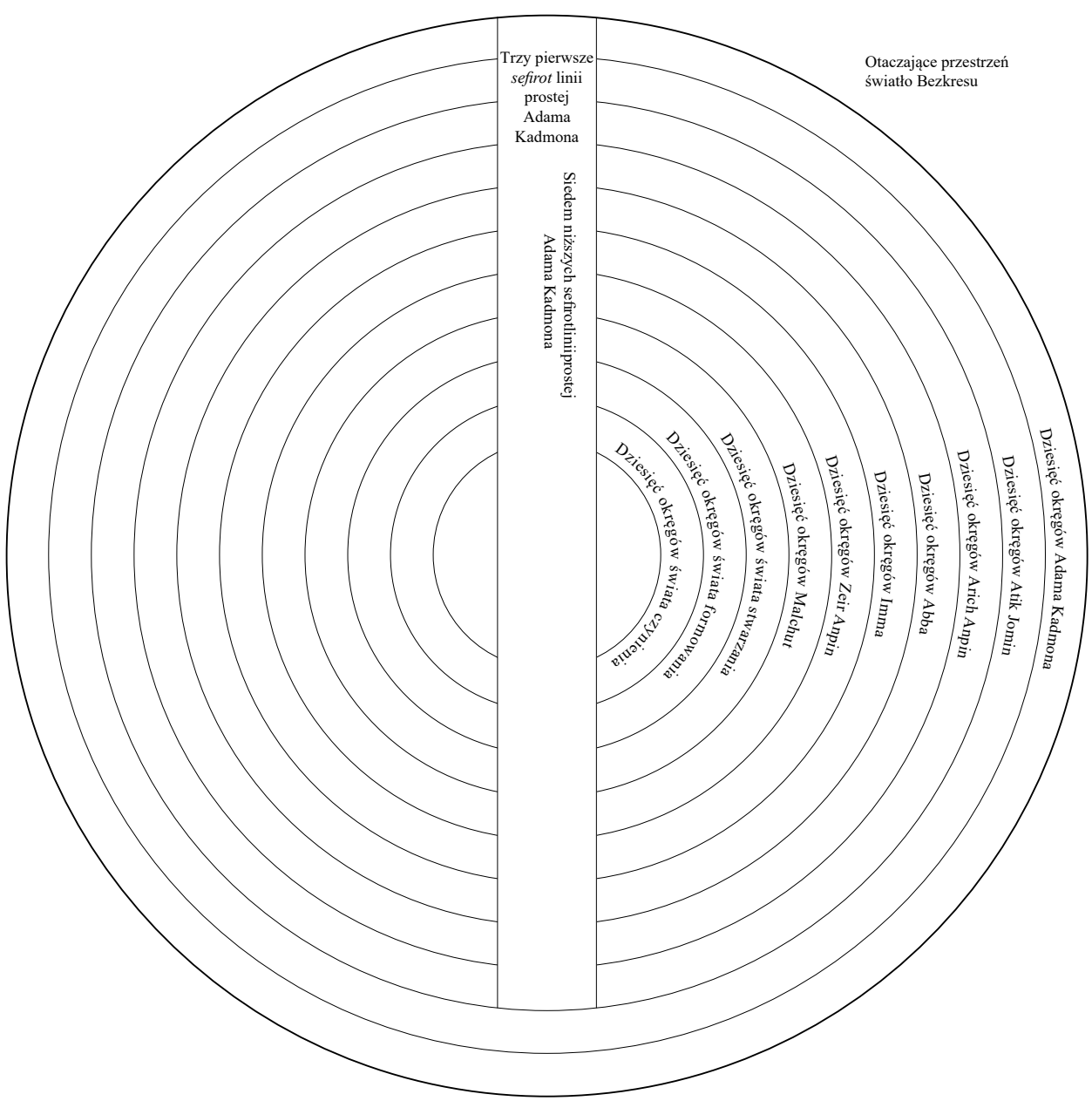

Dynamika interakcji pomiędzy sefirot $\mathrm{w}$ formie okręgów i sefirot linii prostej. Dziesięć okręgów Adama Kadmona wchodzi $\mathrm{w}$ interakcję z trzema pierwszymi sefirot linii prostej. Pozostałe siedem niższych sefirot linii prostej ekspanduje w obrębie przestrzeni i wypełniających ją sefirot $\mathrm{w}$ formie okręgów. 
Kabała luriańska skupia się dominująco na parcufim i sefirot linii prostej, gdyż tylko one są bezpośrednio podatne na wpływ kierowanej wolną wolą aktywności teurgicznej człowieka, w której wyjątkową i wyłączną rolę odgrywa społeczność Izraela. Według rabina Frischa: „Jest tak z tego powodu, że stworzenie nastąpiło po to, aby na świat przyszli synowie Izraela i służyli Świętemu, niech będzie błogosławiony. [...] Wszystkie zaś jego [Praczłowieka] dzieła naprawy [tikkunim] dokonują się, jak wspomniano, poprzez linię prostą, zatem istotę ujawnienia tajemnic w tej książce stanowi przekazanie wiedzy o sposobach naprawy tego, co w górze, która zachodzi mocą tego, co dolne za sprawą synów Izraela. Dzięki naprawie linii prostej za sprawą ich mocy naprawiają się również światy występujące w formie okręgów"37.

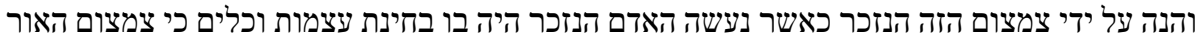

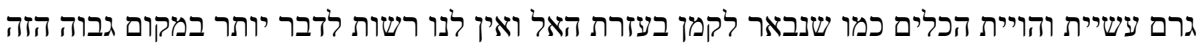

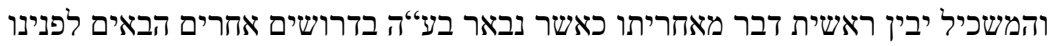

Oto zatem za sprawą wspomnianego samoograniczenia, gdy uczyniono wspomnianego czlowieka, występował $w$ nim aspekt istoty i naczynia. Ograniczenie światla spowodowało uczynienie i istnienie naczyń, co objaśnimy poniżej $\mathrm{z}$ boską pomocą. Nie wolno nam więcej mówić o tym wysokim miejscu, człowiek zaś rozumny [maskil] zrozumie początek rzeczy z jej kresu. Objaśnimy to $\mathrm{z}$ pomocą ha-Szem $w$ innych, nadchodzących komentarzach.

Rozróżnienie aspektów istoty (acmut) i naczynia (keli) odnosi się do wyobrażenia, zgodnie z którym światło występujące we wszystkich sefirot jako ich istota jest to samo, zróżnicowanie zaś wynika z pozycji danej sefiry w systemie, wyznaczającej jej odmienność jako naczynia, powstałego ze światła umniejszonego.

האמנם אינו כלי ממש אלא שבערך האור שבתוכו נק' כלי אמנם הוא זך ובהיר בתכלית הבהירות והדקות והזיכוך. - n מינו כלי

Jednak w rzeczywistości nie ma naczynia, lecz to światło $w$ jego wnętrzu [Praczlowieka] nazywa się naczyniem tylko w przybliżeniu. Jest ono przejrzyste i jasne skrajną jasnością, wielce subtelne i oczyszczone.

Zdaniem rabina Frischa, wprowadzona dystynkcja nie ma jednak charakteru absolutnego, lecz wyłącznie heurystyczno-dydaktyczny. Obowiązuje

37 Ocarot Chajim..., s. 13:

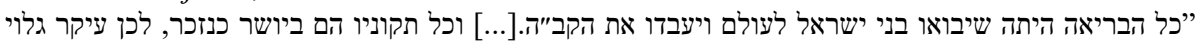

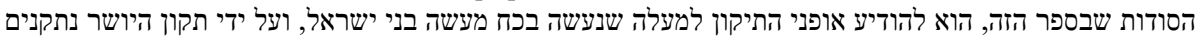


ona wyłącznie z ludzkiej perspektywy poznawczej. Nie wszyscy kontynuatorzy myśli luriańskiej zgadzali się z tym ujęciem. Przeciwny mu był duchowy spadkobierca Gaona z Wilna i wybitny przedstawiciel kabały litewskiej, rabin Szlomo Eljasziw, dla którego wprowadzone rozróżnienie pomiędzy sefirot oraz ich aspektami istoty i naczynia mają obiektywny bytowo charakter. Jednak według rabina Vitala są one ,jak gdyby" (kiwjachol) obiektywne, co zbliża jego stanowisko do mistycznej wersji pragmatycznego fikcjonalizmu, podporządkowanego nadrzędnemu celowi, którym jest naprawa pleromy i człowieka - tikkun.

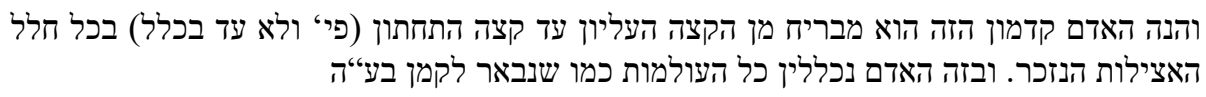

Oto zaś ten Praczlowiek rozciąga się [mawriach] od górnego do dolnego kresu w całej przestrzeni wspomnianej emanacji. W tym też Czlowieku zawierają się wszystkie światy, co z pomocą ha-Szem objaśnimy poniżej.

Postać Praczłowieka odpowiada stanowi doskonałego zjednoczenia i równowagi zachodzącymi pomiędzy reliktowym światłem śladu (reszimu) oraz światłem linii prostej (qaw ha-jaszar). Zarazem jest to stan uprzedni względem emanacji wszystkich światów. Idea doskonałego zrównoważenia biegunowych przeciwieństw, potencjalnie rozsadzających pleromę, sięga na gruncie mistyki żydowskiej do XIII wieku, w szczególności zaś do pism Azriela z Gerony (ok. 1160-1238) oraz koncepcji działającego w Toledo (1230-1260) ezoterycznego kręgu Ijjun z jego pojęciem niezróżnicowanej jedności (achdut ha-szawe $)^{38}$.

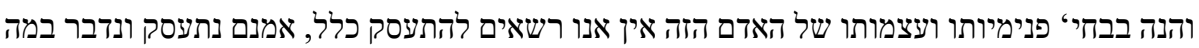

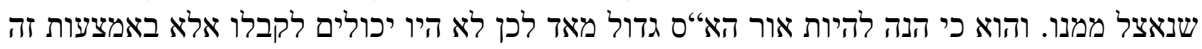

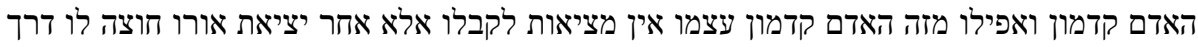
הנקבים והחלונות שבו שהם האזנים והעינים החוטם והפה וכמו שנבאר למטה בעזירת הארת האל.

Oto zaś w odniesieniu do aspektu wewnętrzności i istoty tego Czlowieka nie mamy w ogóle prawa, aby się tym zajmować. Zajmiemy się jednak i omówimy to, co zostało $\mathrm{z}$ niego wyemanowane. Poniewaź światlo Bezkresu było zbyt wielkie, dlatego nie mogli go przyjąć inaczej, jak tylko za pośrednictwem tego Praczlowieka. Nawet jednak w odniesieniu do tego Praczlowieka żadna rzeczywistość nie może go przyjmować z jego istoty. Jest to możliwe dopiero po zstąpieniu jego światla na zewnątrz poprzez znajdujące się w nim otwory i okna. Są nimi: uszy, oczy, nos i usta, co objaśnimy poniżej z boską pomocą.

${ }^{38}$ M. Verman, The Books of Contemplation. Medieval Jewish Mystical Sources, New York 1992, s. 39, przyp. 10 . 
$\mathrm{Na}$ tym rabin Vital kończy rozdział I. Wszystkie dotychczasowe procesy kulminują w pojawieniu się głowy Praczłowieka. Ekspandując z niej przez otwory narządów zmysłowych, światło Bezkresu przyjmuje w dalszej kolejności postać czterech wartości liczbowych, odpowiadających czterem możliwościom gematrycznej interpretacji wartości pełnych nazw liter Tetragramu: $72,63,45,52^{39}$.

\title{
LIGHT FROM INFINITY - THE ORIGIN OF THE PLEROMA ACCORDING TO THE WORK of Ocarot Chaim (Treasures of Life) by r. Chaim Vital - Introduction, Translation, COMMENTARY
}

\begin{abstract}
The presented text contains an introduction, translation and commentary on the stages of the manifestation of the deity and the pleromatic emanation presented in the Ocarot chajim (Treasures of Life) treatise by rabbi Chajim Vital, a disciple of Isaac Luria. This work is the most systematic display of Lurianic metaphysics. In the introduction, the author situates the position of the treaty in the broader context of Lurianic literature. Then he discusses the differences and similarities between the ancient Hebrew concept of prophetic spirit transmission, and the Gnostic, Platonic and Neoplatonic understanding of the process of emanation. The translated source text and commentary analyze the act of self-contraction of infinity and the emergence of a plerome as given in the form of a dialectical game of linear and circular sefirots until the final emergence of megaanthropos - Adam Qadmon.
\end{abstract}

Keywords: Jewish mysticism, Gnosis, Lurianic Kabbalah, emanationism, plerome

Słowa kluczowe: mistyka żydowska, gnoza, kabała luriańska, emanacjonizm, pleroma

\section{BIBLIOGRAFIA}

Afilalo R., Kabbalah Dictionary, b.m. w., 2005.

Anonim, Derech le-Ec chajim. Tarszimej hesber le-hawanat sefer Ec Chajim, Szaar ha-kawwanot u-moadim, Tiferet Szlomoh 5767/2007.

39 Zastosowano następujący sposób rachuby: imię $a$ "w (72): jud (10+6+4) - hej (5+10) - wajw (6+10+6) - hej (5+10); imię s"ag (63): jud (10+6+4) - hej (5+10) - waw (6+1+6) - hej (5+10); imię m"ah (45): jud (10+6+4) - he (5+1) - waw (6+1+6) - he (5+1); imię b"en (52): jud $(10+6+4)$ - he $(5+5)-$ waw $(6+6)-h e h(5+5)$. 
Awiwi J., Kabalat ha-Ari, t. I-III, Jerozolima 5768.

Biblia Jerozolimska, Poznań 2006.

Biblioteka z Nag Hammadi. Kodeksy I i II, thum. i kom. W. Myszor, Katowice 2008.

Chalfon Chaim E., Milon 'iwri kabbali, Nof Ajjalon 5758/1998.

Diels H., Kranz W., Die Fragmente der Vorsokratiker, t. I, Berlin-Neuköln 1960.

Eco U., Czytanie świata, tłum. M. Woźniak, Kraków 1999.

Eco U., O zwierciadtach, w: U. Eco, Czytanie świata, tłum. M. Woźniak, Kraków 1999, s. 65-102.

Fine L., Physician of the Soul, Healer of the Cosmos. Isaac Luria and His Kabbalistic Fellowship, Stanford 2003.

Fishbane E.P., As Light Before Dawn. The Inner World of a Medieval Kabbalist, Stanford 2009.

Goldberg A.M., Untersuchungen über die Vorstellung von der Schekhinah in der frühen rabbinischen Literatur, Berlin 1969.

Goldberg O., Rzeczywistość Hebrajczyków, tłum. T. Sikora, Kraków 2012.

Grözinger K.E., Jüdisches Denken. Theologie - Philosophie - Mystik, Frankfurt-New York 2005.

Hipostaza archontów (87, 11 i n.), w: Biblioteka z Nag Hammadi. Kodeksy I i II, thum. i kom. W. Myszor, Katowice 2008.

Historisches Wörterbuch der Philosopie, t. IV, red. K. Gründer, Basel 1976.

Idel M., Kabała. Nowe perspektywy, thum. M. Krawczyk, Kraków 2006.

Jonas H., Religia gnozy, tłum. M. Klimowicz, Kraków 1994.

Kafasjan D., Sefer Ec chajim sze be-gan, [b.m.w.] 5769/2009.

Kirk G.S., Raven J.E., Schofield M., Filozofia przedsokratejska, Warszawa 1999.

Kohen-Alloro D., Sod ha-malbusz u-mareh ha-malaach be-sefer ha-Zohar, Jeruszalajim 1987.

Kordowero M., Pardes rimmonim, Jeruszalajim 5760/2000.

Meroz R., Geula ba torat ha-Ari, Jerozolima 5748.

Mincha le-Sara. Mechkarim ba-filosofija jehudit u-wa-qabbala mugaszim la-profesor Sara Heller Wilenski, red. M. Idel, D. Dimant, S. Rozenberg, Jeruszalajim 1994.

Necker G., Einführung in die lurianische Kabbala, Frankfurt a. M. 2008.

Pachter M., Circles and Straightness, w: M. Pachter, Roots of Faith and Devequt. Studies in the History of Kabbalistic Ideas, Los Angeles 2004, s. 131-184.

Pachter M., Roots of Faith and Devequt. Studies in the History of Kabbalistic Ideas, Los Angeles 2004.

Poimandres, tłum., kom. i wstęp W. Myszor, „Studia Theologiae Varsoviensis”, 15 (1977), nr 1, s. proszę podać zakres stron.

Reallexikon für Antikes und Christentum, red. Th. Klauser, t. IV, Stuttgart 1959.

Roi B., Ahawat ha-Szechina. Mistika u-poetika ba-Tikkunej Zohar, Ramat Gan 5767/2007.

Rudolf K., Gnoza. Istota i historia późnoantycznej formacji religijnej, tłum. G. Sowiński, Kraków 2003.

Scholem G., Celem - wyobrażenie ciała astralnego, w: G. Scholem, O mistycznej postaci bóstwa, thum. A.K. Haas, Warszawa 2010, s. 297-329.

Scholem G., O mistycznej postaci bóstwa, thum. A.K. Haas, Warszawa 2010.

Scholem G., Szechina - bierno-żeński moment $w$ bóstwie, w: G. Scholem, O mistycznej postaci bóstwa, thum. A.K. Haas, Warszawa 2010, s. 157-226.

Shuchat R., Hagigim al qabbalat Lita. Ijun be-sugijat igulim we-joszer, w: Mincha le-Sara. Mechkarim ba-filosofija jehudit u-wa-qabbala mugaszim la-profesor Sara Heller Wilenski, red. M. Idel, D. Dimant, S. Rozenberg, Jeruszalajim 1994, s. 11-32.

Stownik grecko-polski, red. Z. Abramowiczówna, Warszawa 1958.

Stoichita V.I., Krótka historia cienia, tłum. P. Nowakowski, Kraków 2001.

Szaron Szatil, Ha-Ari. Sippura we-haguta szel mahapechat ha-kabbalah bi-Cefat, Tel Awiw 2007.

Verman M., The Books of Contemplation. Medieval Jewish Mystical Sources, New York 1992.

Vital Ch., Sefer Ocarot chajim im pejrusz Matok mi-dewasz (Księga «Skarbce życia» z komentarzem «Stodszy od miodu»), t. I, Jeruszalajim 5768/2008. 